\title{
تشييء الشخصيات في الرواية الجديدة
}

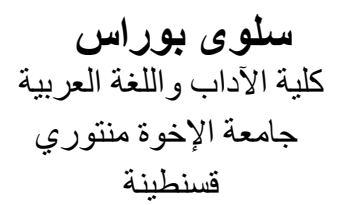

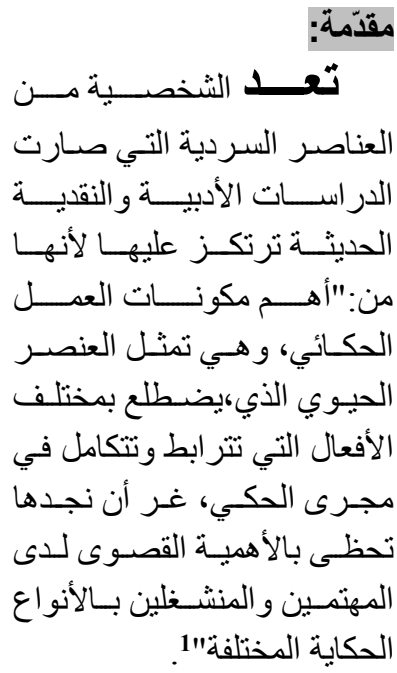

\section{Abstract:}

The Character was a prominent and effective place in narrative text in the 19th century, where it was able to find an independent place away from its association with the main event, contrary to the traditional novel, which considered a just a name that strengthens it, as all the elements of narration work aim to highlight the character and impose its presence in all situations and the differences within the novel. This element is also characterized by from other narrative elements with a sum of features that distinguish it from others, through the term «Characters objectification ".

Key words: The new novel, the objectification, character obliteration. 
جاء في المعجم الوسيط أنها:"صفات تميز الثخص عن غيره، ويقال فلان ذو شخصية قوية، أي ذو

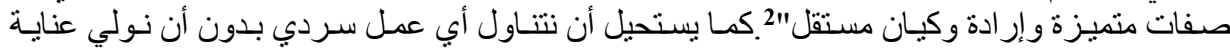

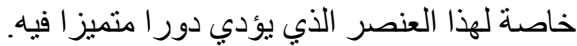

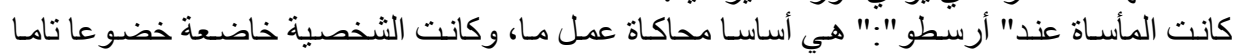

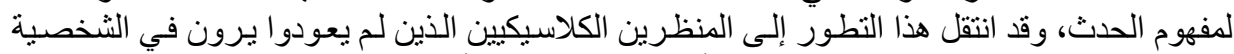

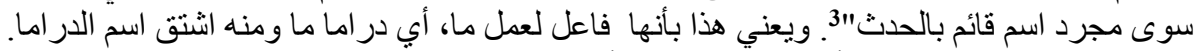

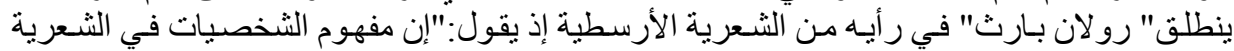

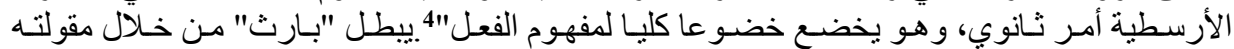

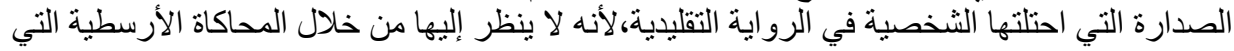

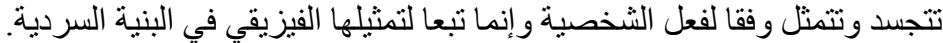

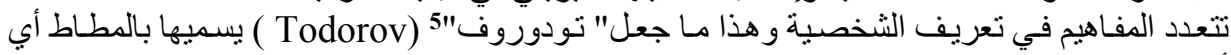

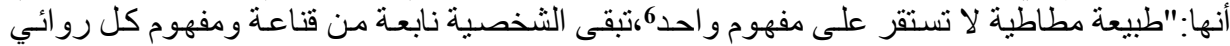

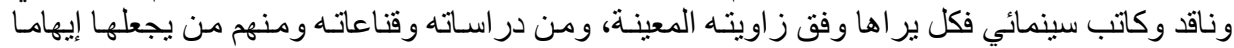

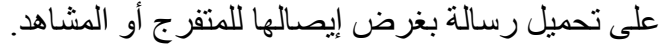

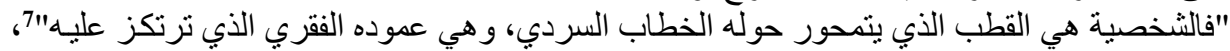

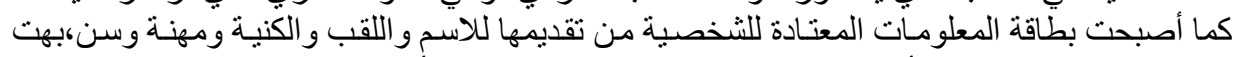

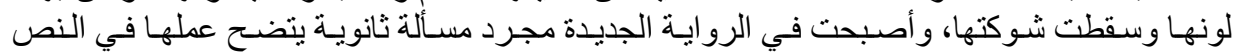

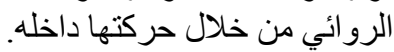

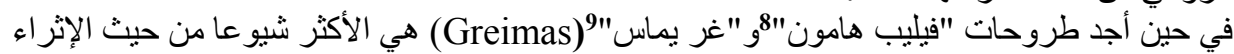

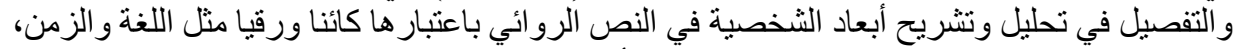

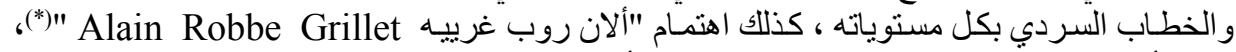

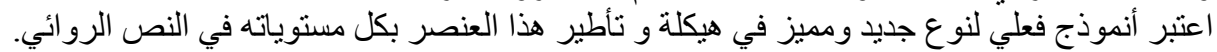

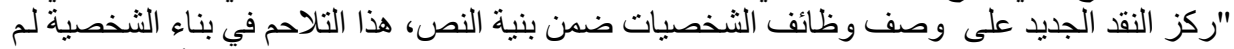
يظهر إلا بداية القرن العشرين مع الثكلانيين الروس (Formalisme Russe

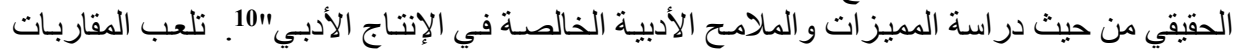

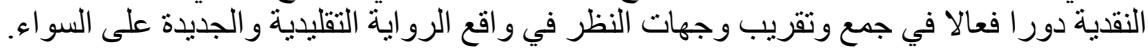

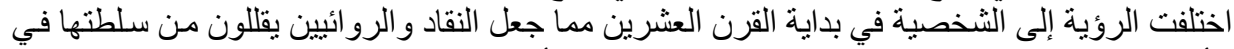

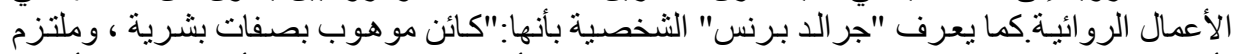

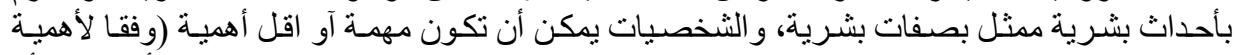

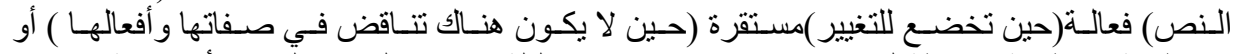

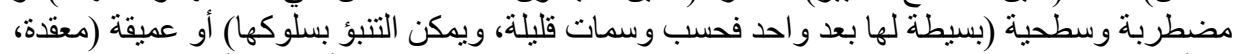

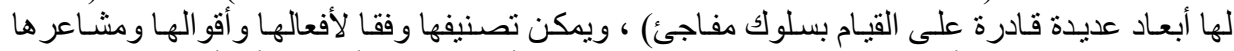

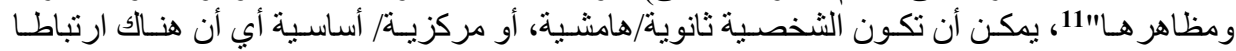
و اضحا بين الثخصية الحقيقية و الروائية.

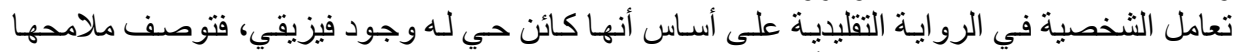

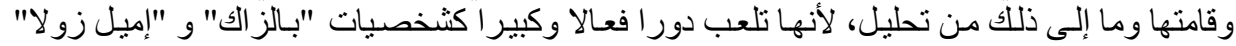

\section{1- 1 الثخصية في الرواية الجديدة:}

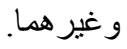

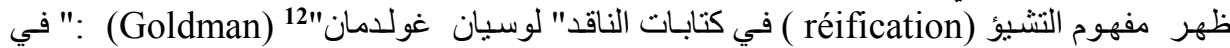

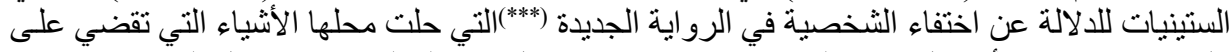

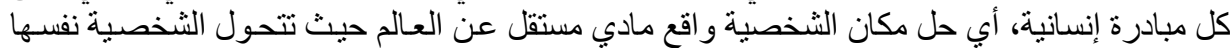
إلى موضوع تبادل إلى شيء مستقل عن نثاطها وإلى إدنها"13، حيث فسره على على انه تلاعب التعبير الفني 
عن تحول الر أسمالية الليير الية إلى مجتمع الاحتكار ات الذي لم يعد السوق فيه يخضع لو عي الفرد المنظم

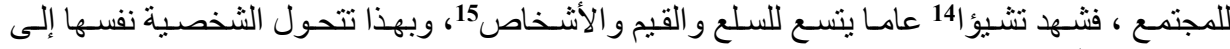

شخص مستقل عن نشاطها و إر ادتها.

احتلت الثخصية مكانا بارزا ولعبت دور الثنا فعالا في النص الروائي الجديد " الأحداث نفسها مبنية أ ساسـا

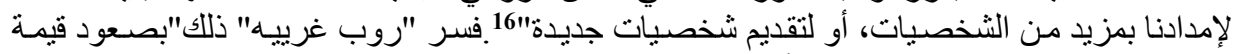

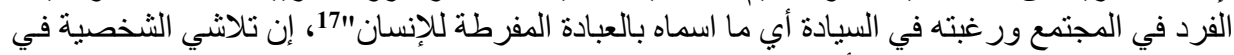

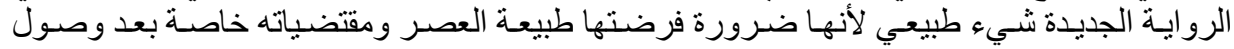

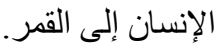

كما يؤكد "روب غرييه "بدوره أن "العصر الحاضر هو بالأخص عصر الأرقام، والحق انه عندما ير اد اد الدئ

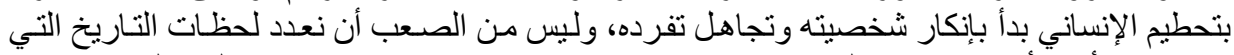

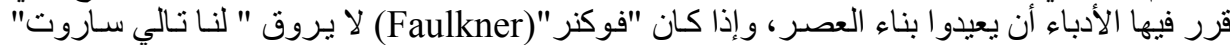

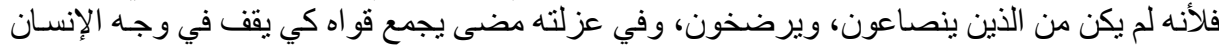

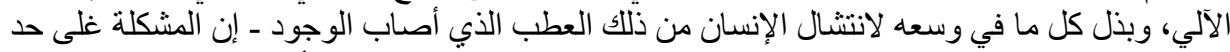

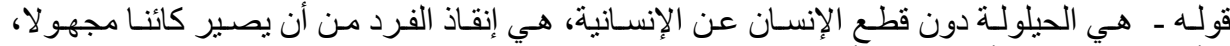

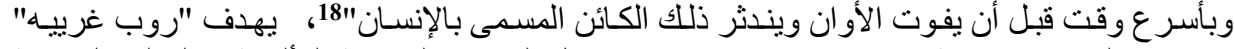

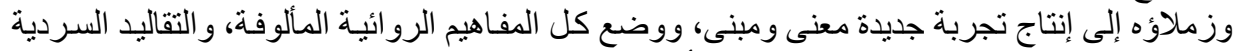

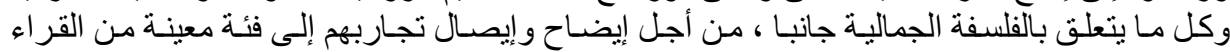

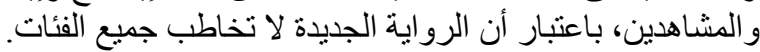
هكذا يتم إلغاء الثخصية في الرواية الجديدة عبر مسلكين الأول عن طريق طمسهـا والثانية عن طريق مطالبتها و اتهامهاه . مئمئ. عبرت الثخصية في الرواية الجديدة "عن الو اقع الجديد شكلا ومضمونا، كمـا أنها في الروايـة أمارة

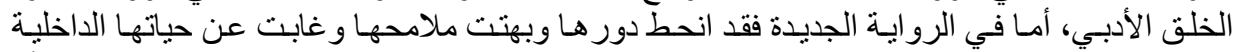

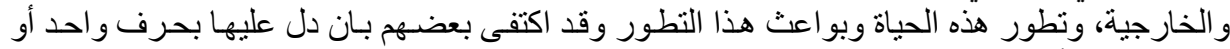

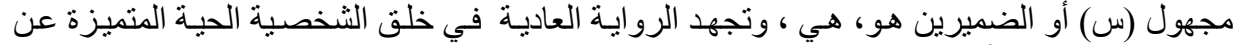

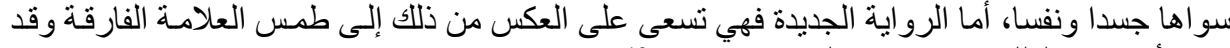

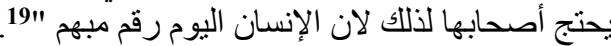

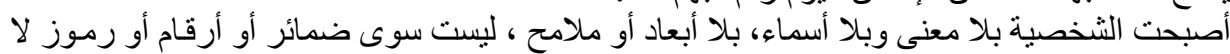

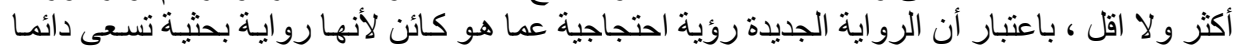
ورواء الجديد.

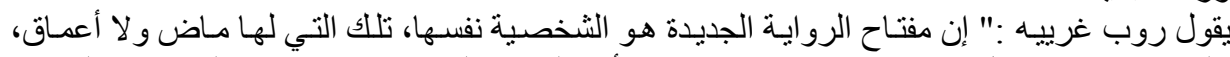

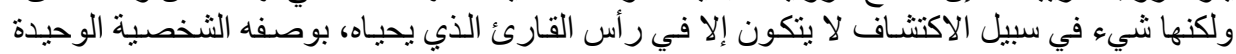

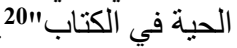

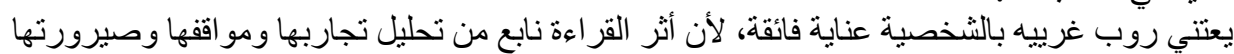

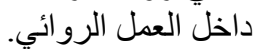

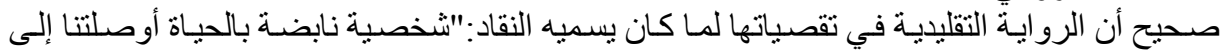

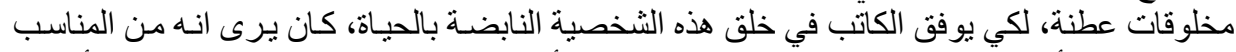

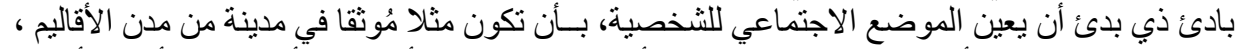

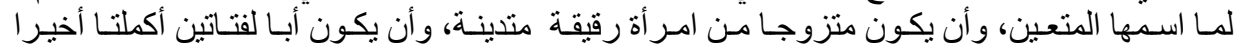

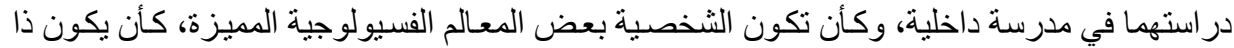

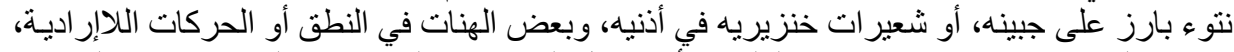

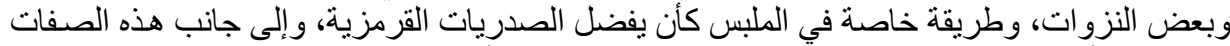
المعنوية، كأن يكون صـارما صر امة عسكرية غير متسامح في أمور الفضيلة، لا يخدع في مسائل المـال 


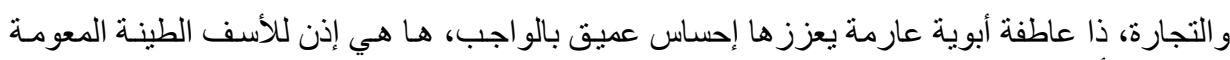

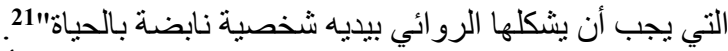

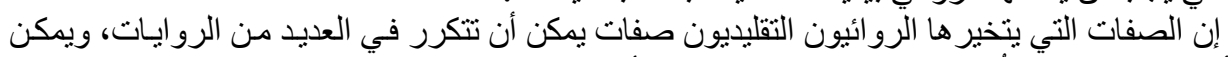

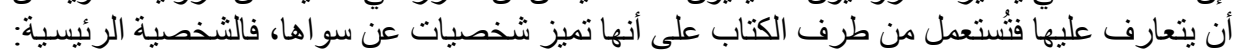

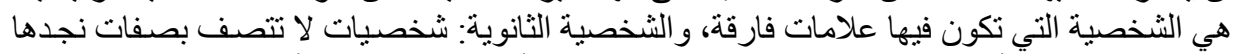

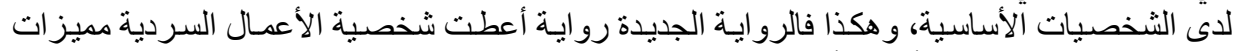

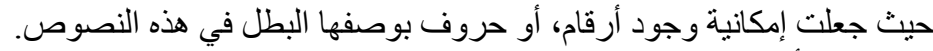

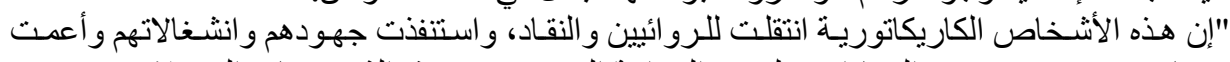

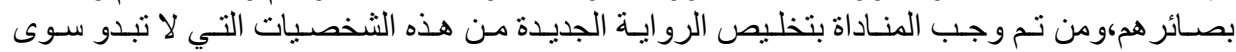

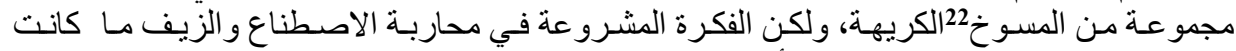

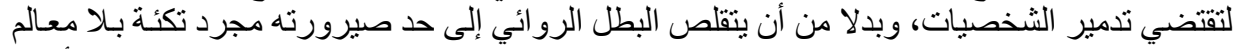

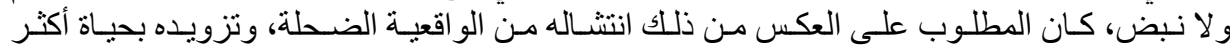

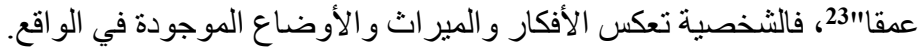

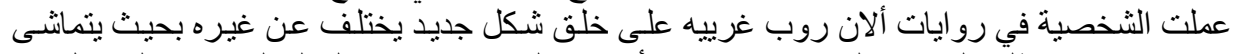
وحساسيات ما يتطلبه القارئ و المشاهد، فهو يرى أن مادة الفن مو جودة في العالم الخـارجي المستقل في في

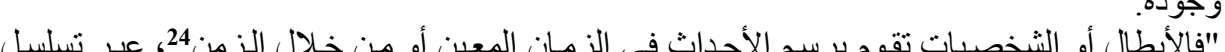

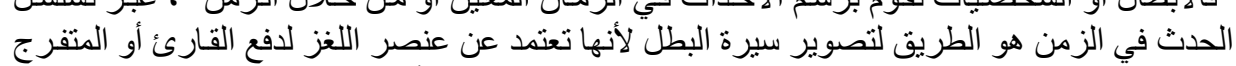

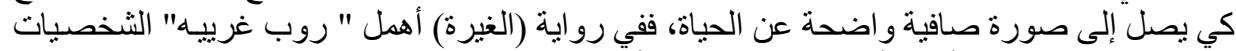

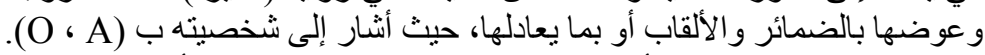

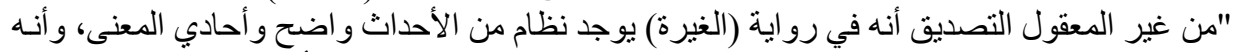

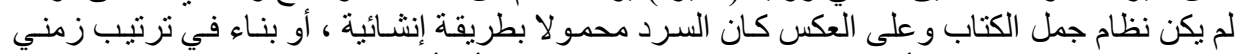
خارجي، سوف تصل آجلا أم عاجلا إلى سلسلة من التناقضات، أبل أبل أنها سوف تصل إلى إلى طريق مسدود

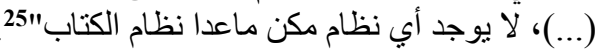

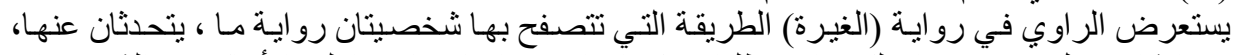

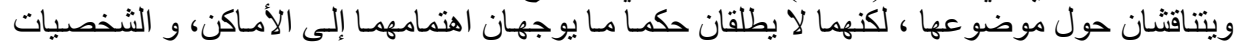

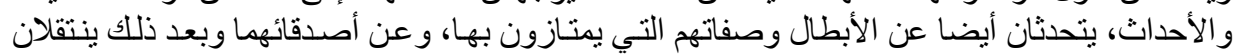

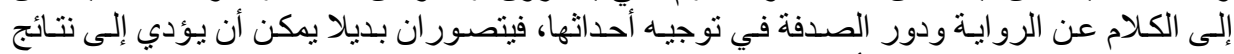

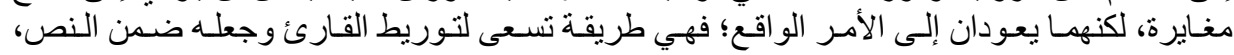
و المخاطبين في هذه الحالة هم القراء.

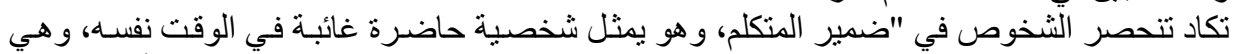

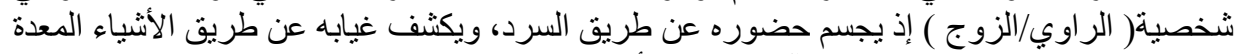

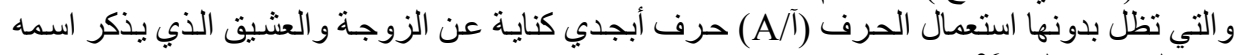

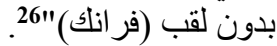

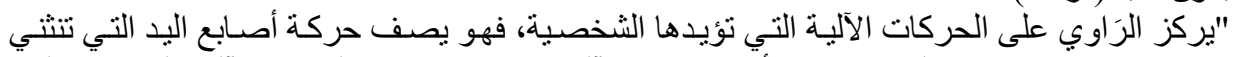

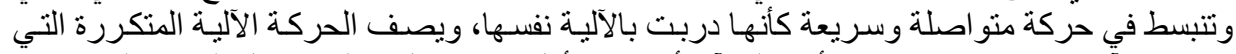

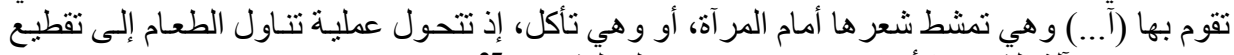

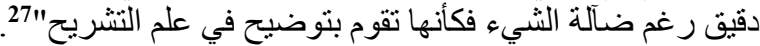

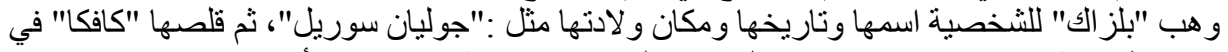

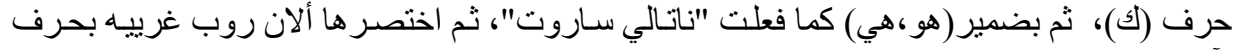




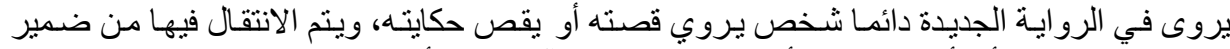

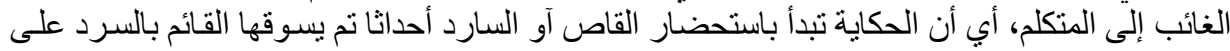

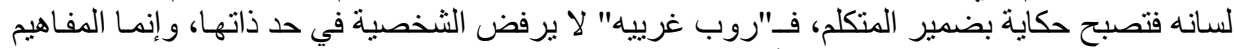

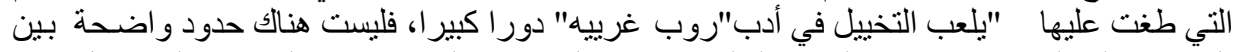

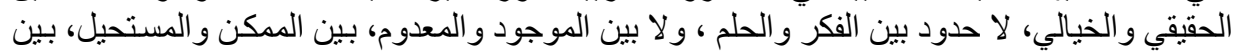

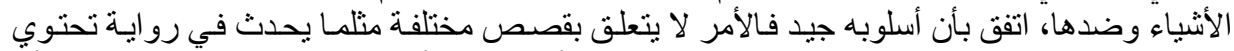

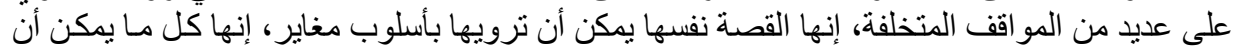

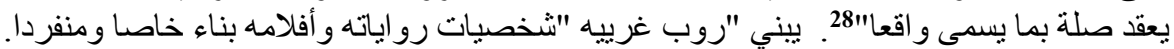

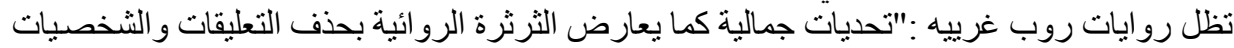

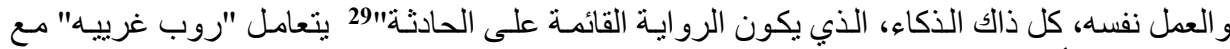
الثخصية و الأشياء بطريقة حيادية لائقة وهي تقنية يعتمدها ليشارك القارئ القارئ و المشاهد في عملية التو اصل

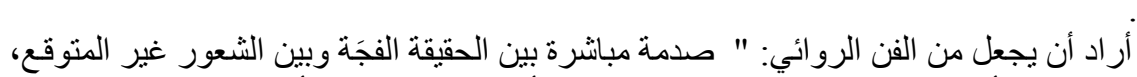

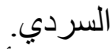

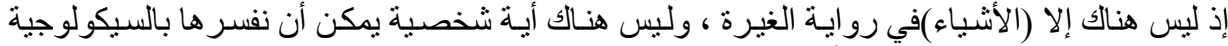

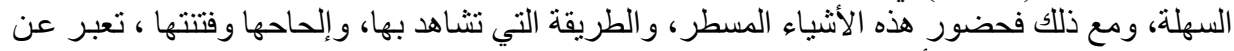

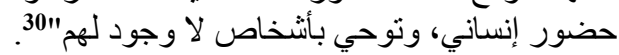

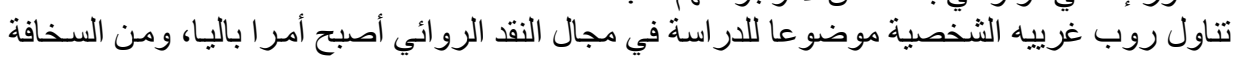

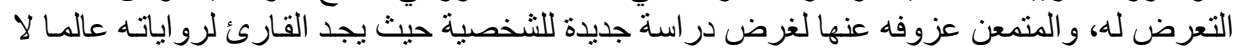

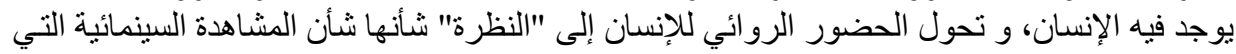

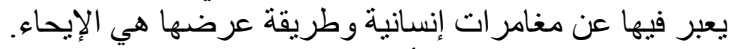

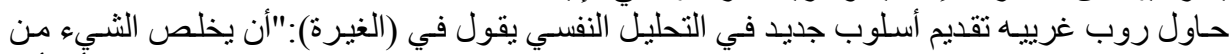

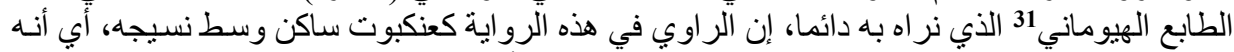

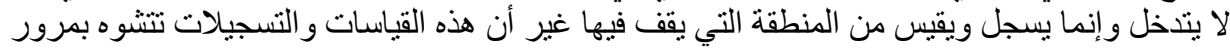

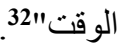

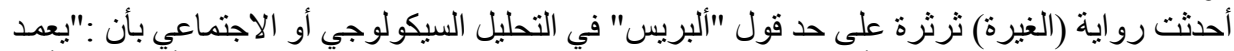

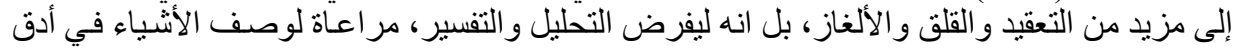

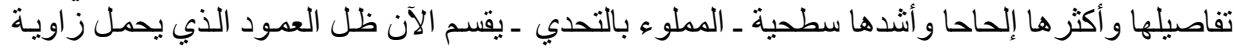

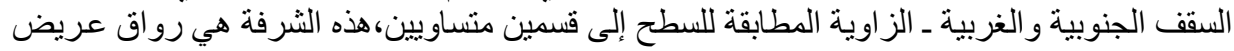

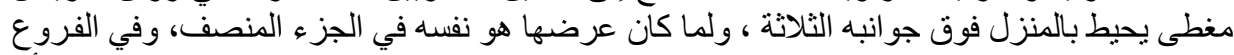

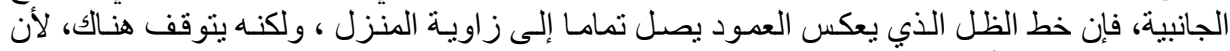

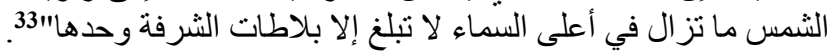

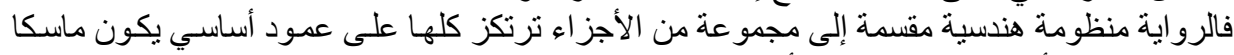

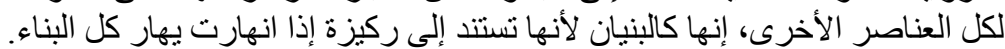

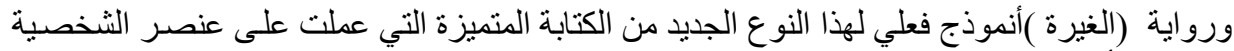

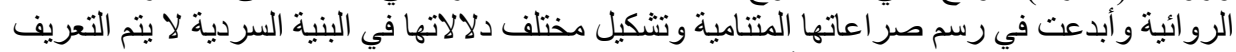

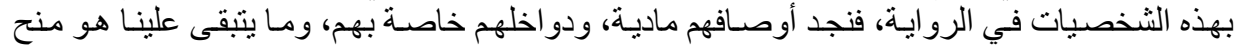

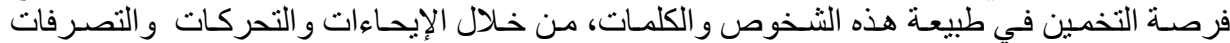

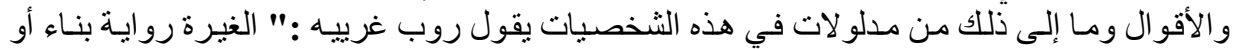

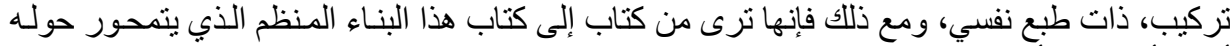
أكثر فأكثر هوةً أو فر اغا مركزيا، في حين يتجلى دوما بناء الرو اية التقليدية حول الملإِ"34ائ. 
تدور رواية (الغيرة) حول قصة الزوجة (آ/A) مع عشيقها "فر انك"(Franck)وترتكز حول الزيارات

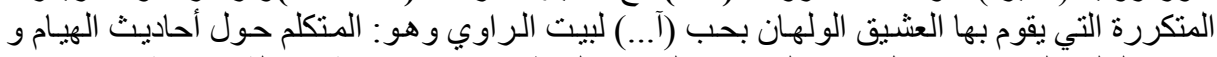
تعابير الولع "التي تدور حول مائدة العشاء، و التناسق العاطئ العاطفي من رومانسية منبادلة متناسقة.

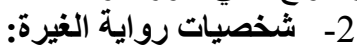

1-4 - 2 - الزوج / الراوي:

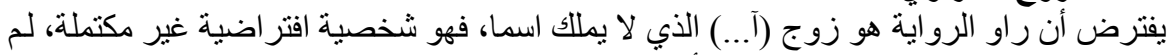

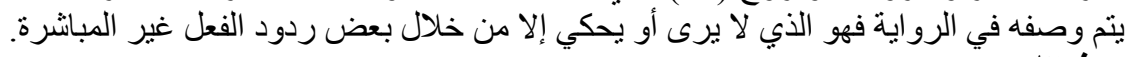

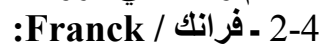

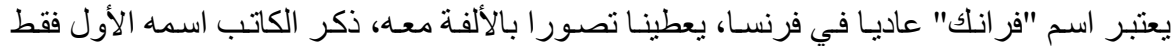

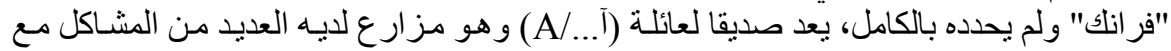
السائقين و الثناحنات.

:(A/....) -3-4

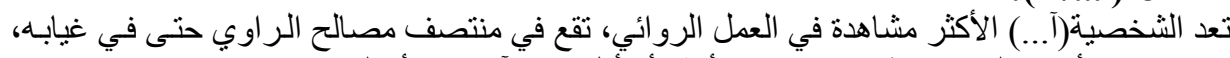

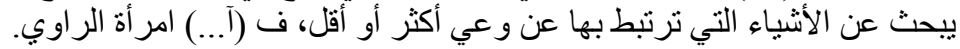

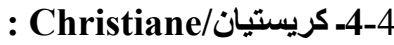

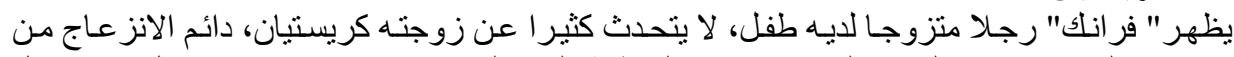

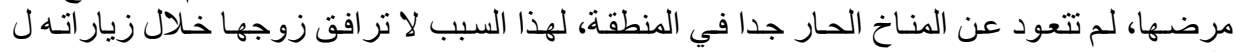

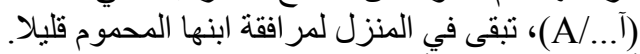

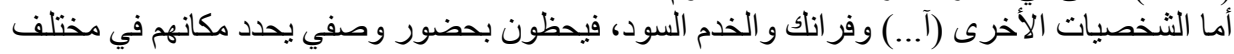

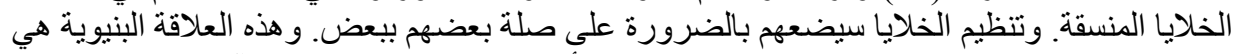

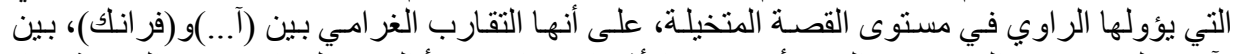

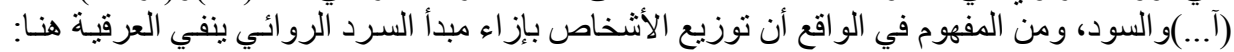

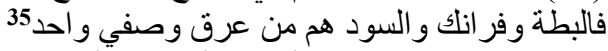
3- شخصيات رواية (السنة الماضيّة في مارينباد):

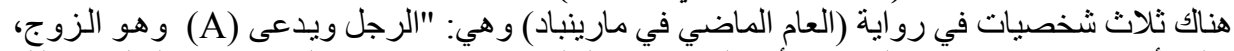

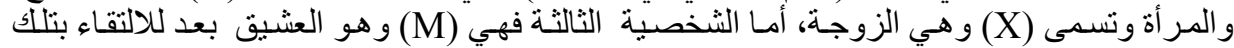

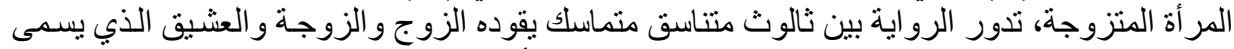

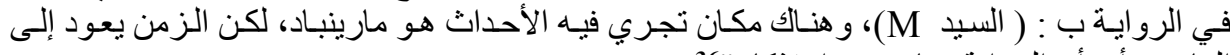

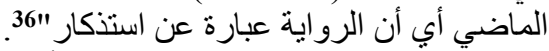

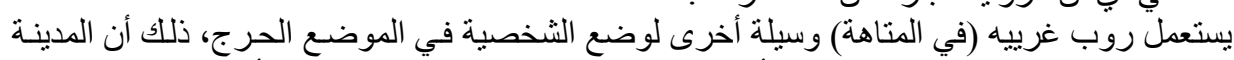

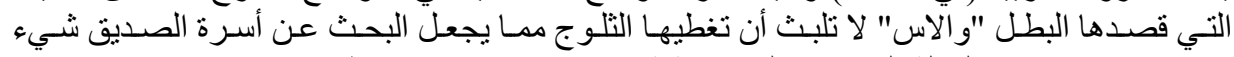

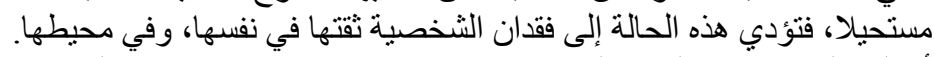

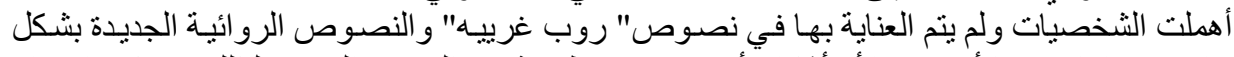

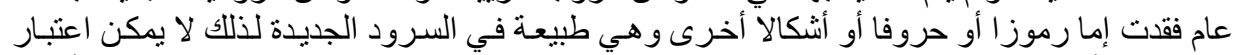

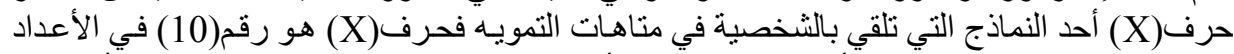

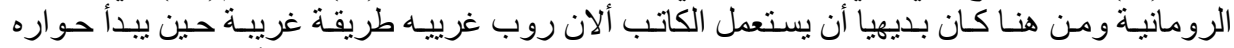

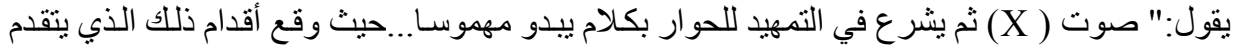

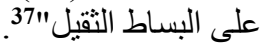

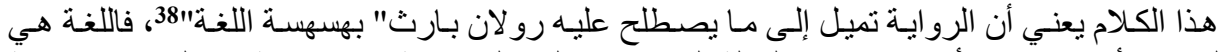

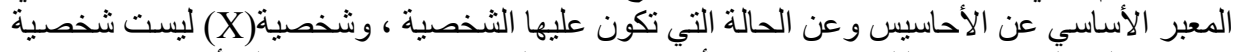

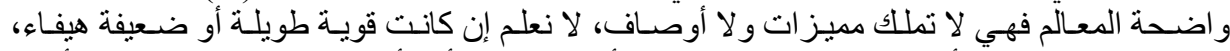
تتجاذب هذه الثخصيةً أطر اف الحديث مع شخصية أخرى نعرف أنها أنثوية من خلال الصفة التهية التي أطلق 
عليها الكاتب يقول:" صوت الممثلة (Vois De La Comédienne)ومثل غير هـا لا نعرف عنها إلا

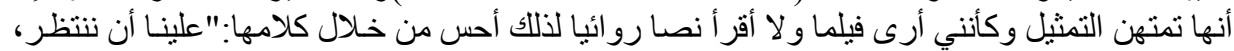

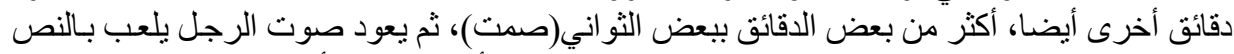

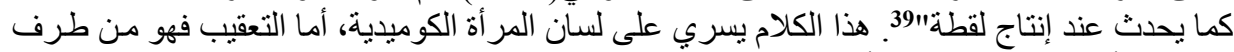

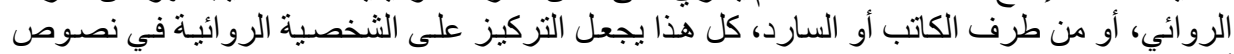
ألان روب غرييه شيئا صعبا.

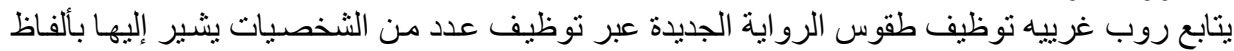

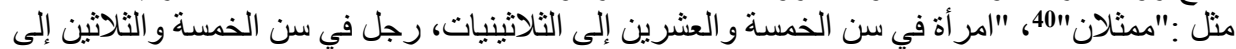

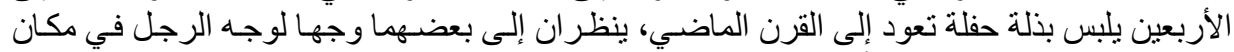

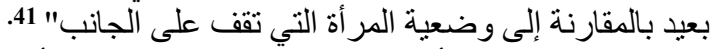

وفي رواية(الغيرة) يبدأ السرد بإطلالة على المكان رغم الفي أن الأحداث تجري في حقول الموز حيث تعمل

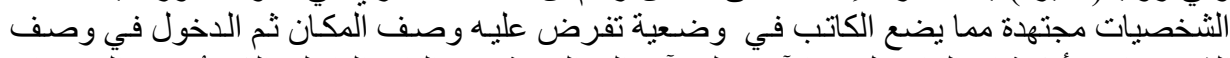

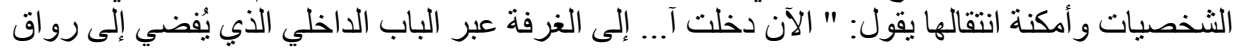

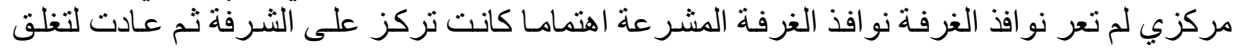

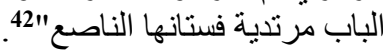

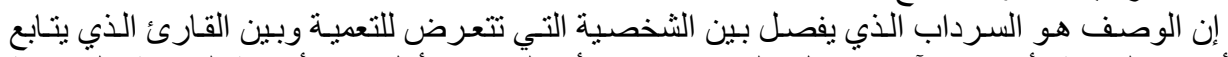

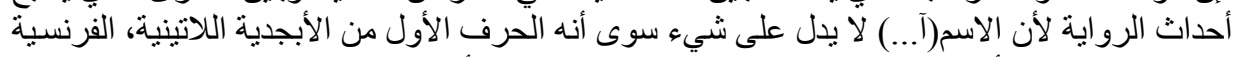

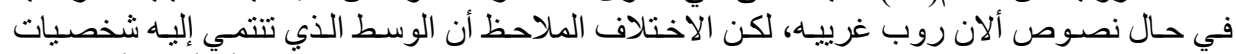

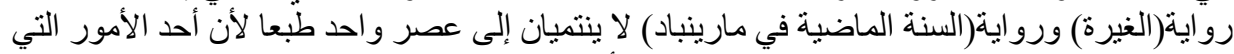
نستشف منها ذلك هو طريقة اللباس وطريقة الحئة الحركة أيضا.

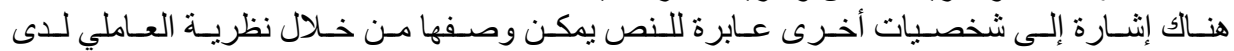

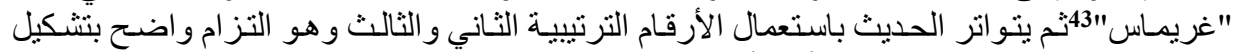

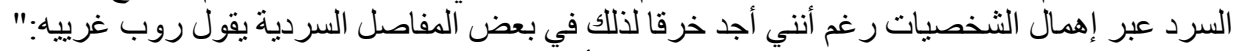

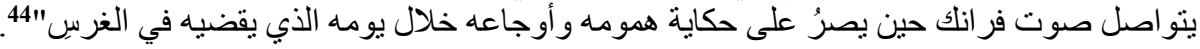

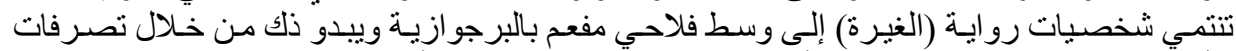

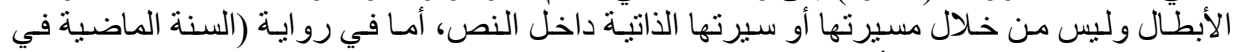

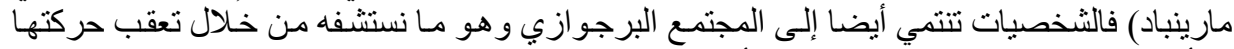

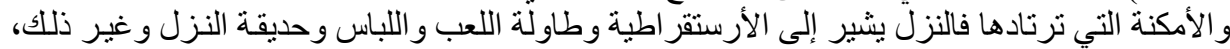

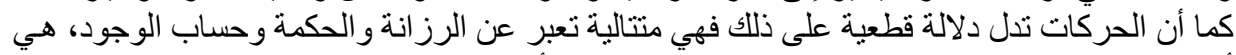

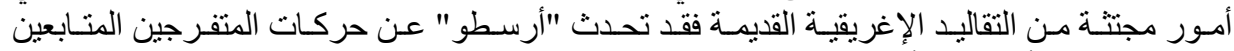

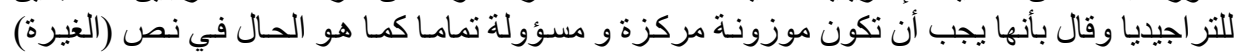

وفي (السنة الماضية في مارينباد)

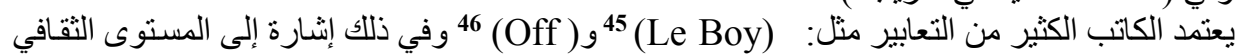

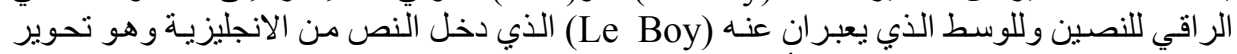

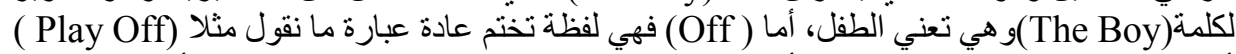

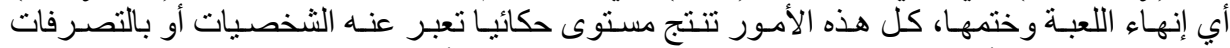

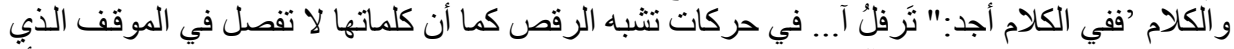

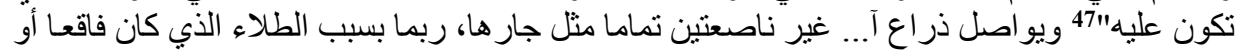

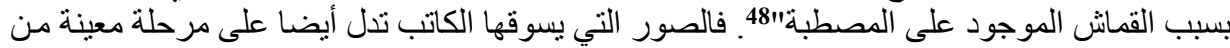

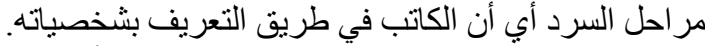

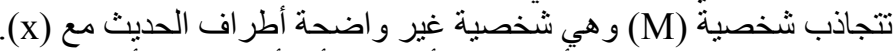

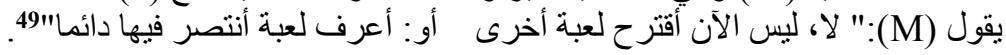




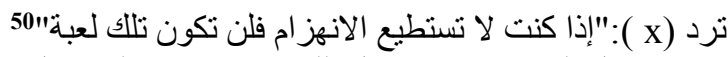

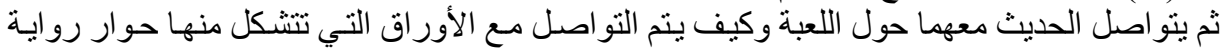

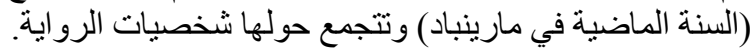

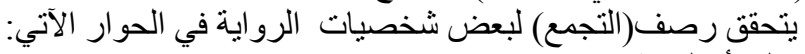

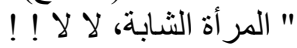

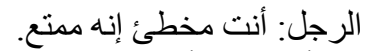

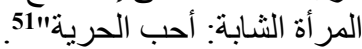

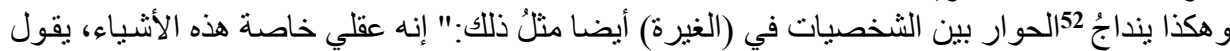

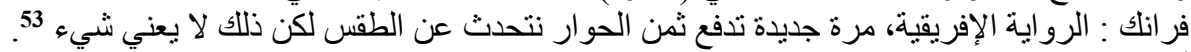

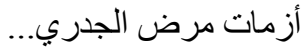
هناك حبوب الكنين 54

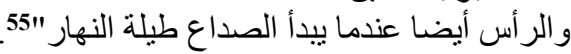
خاتمة:

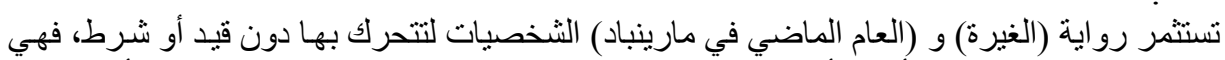

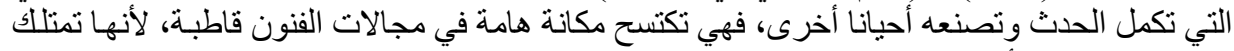

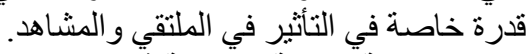

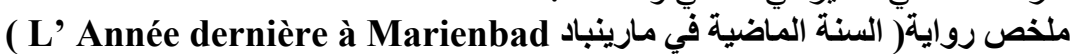

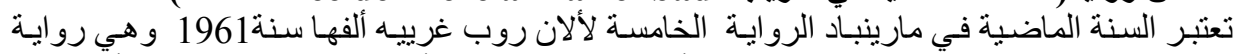

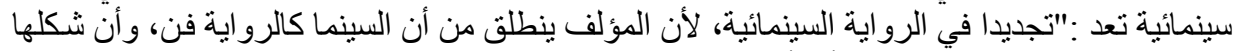

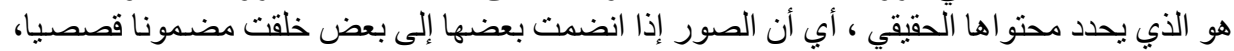

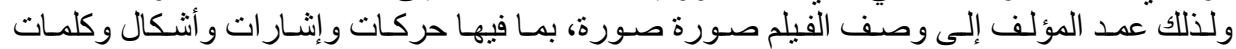

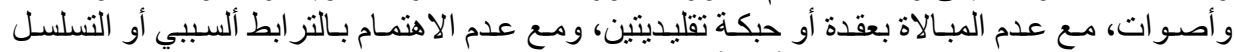

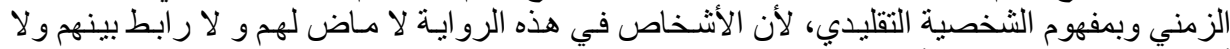

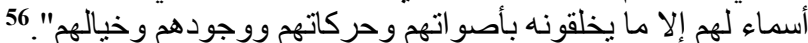

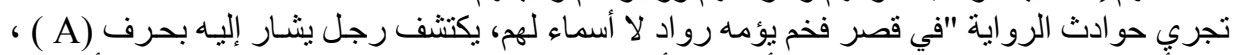

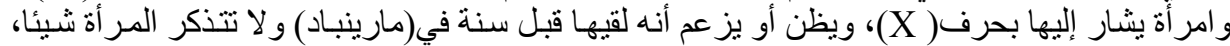

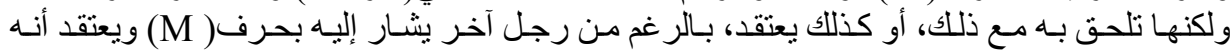
زوجها".

إن الحو ادثا" التي يصفها ألان روب غرييه في نصه هذا بطيئة لكنها تتميز بالضبابية ممـا يُحسس القارئ

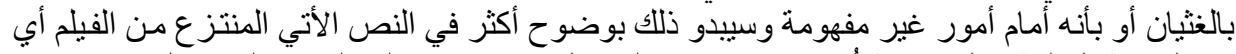

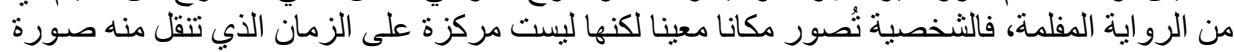

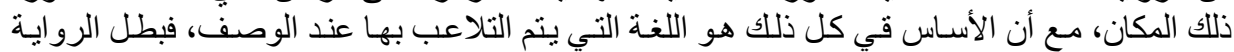

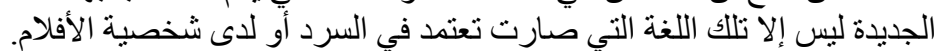

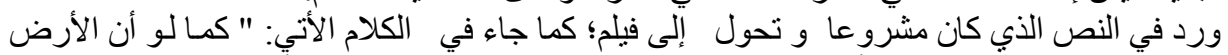

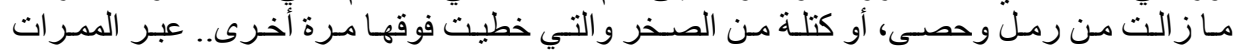

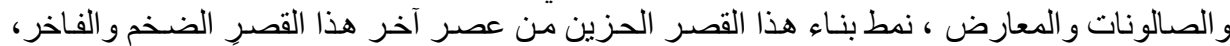

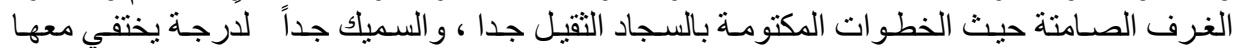

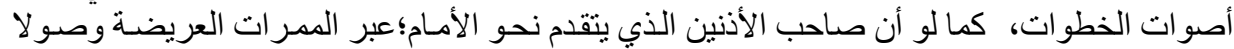

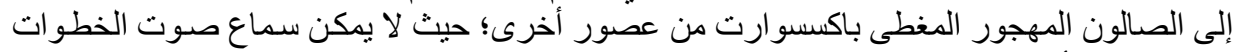

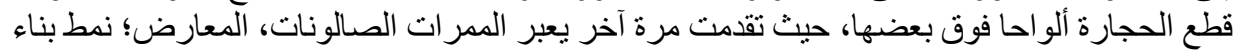

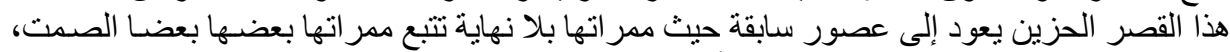

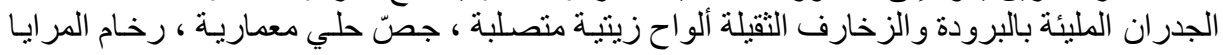




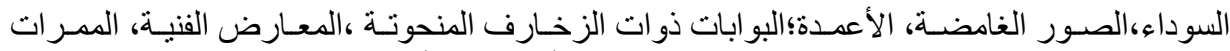

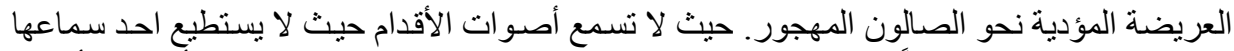

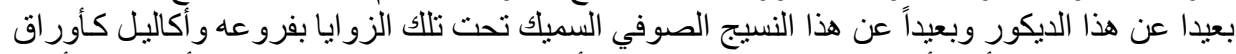

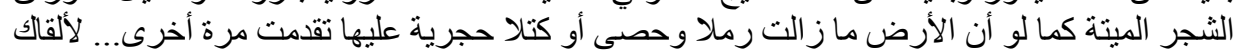

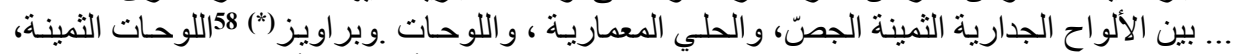

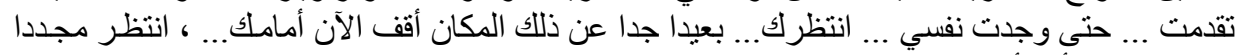
ذلك الذي لن يأتي أبدا ذلك الذّي فرقنا ابعد يدك عني". 59

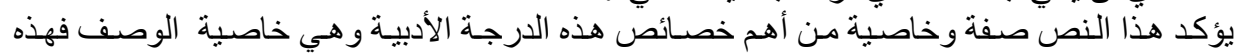

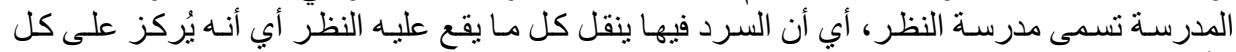

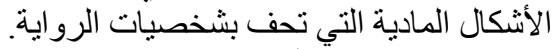

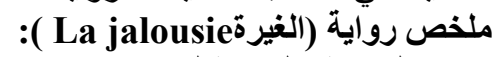

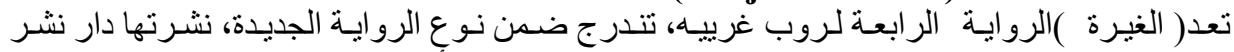

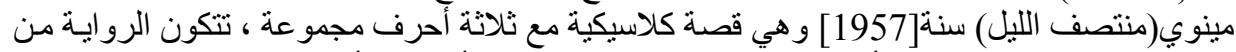

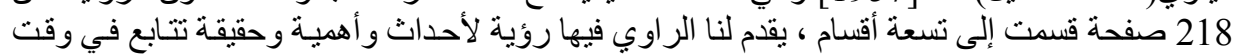

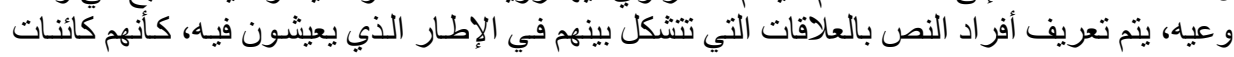

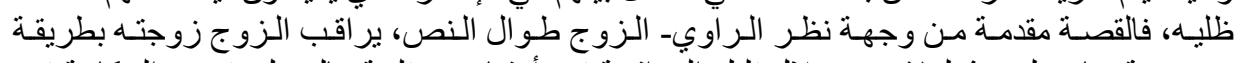

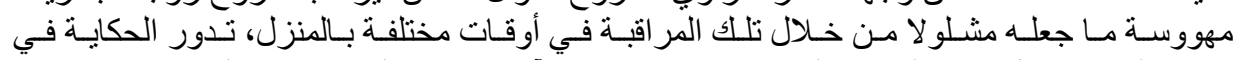

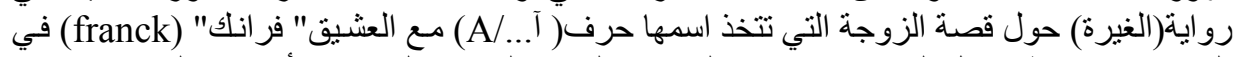

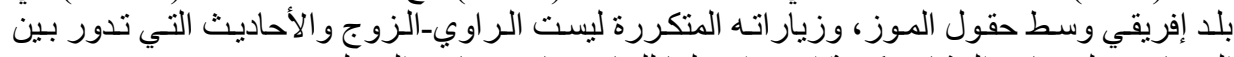

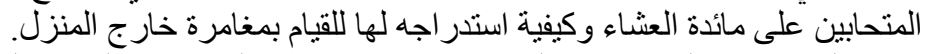

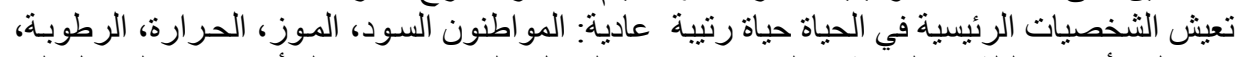

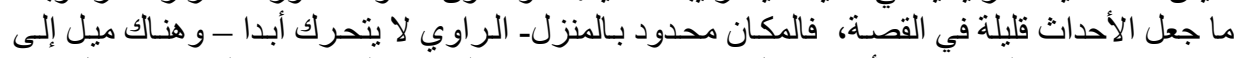

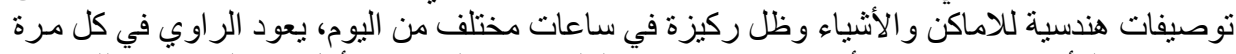

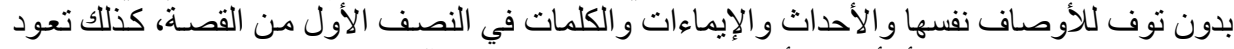

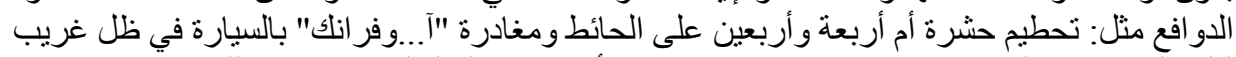

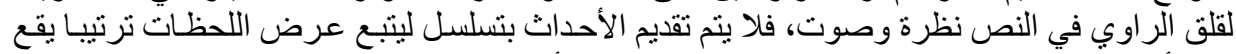

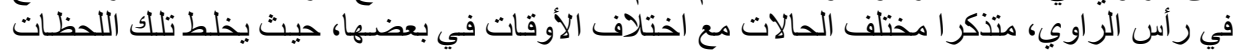

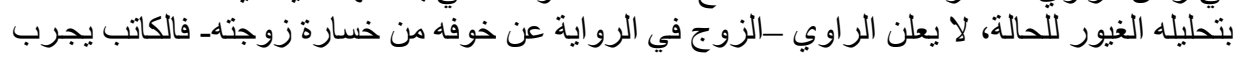

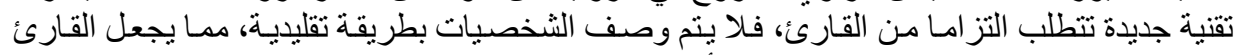

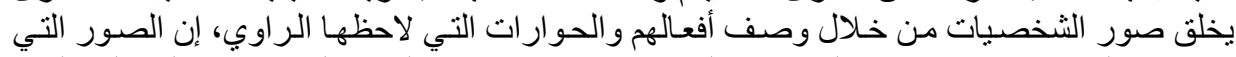

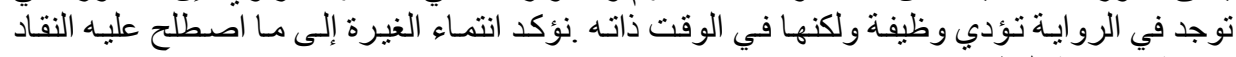

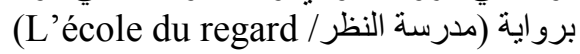


(1) - سعيد يقطين: قال الراوي (البنيات الحائية في السيرة الشعبية)، المركز الثقافي العربي،الدار

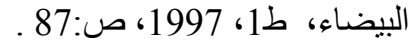

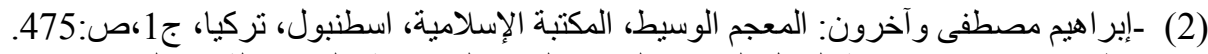

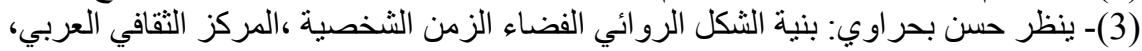

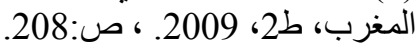

(4)- حسن الأشلم:الثخصية الروائية عند حسين مصطفى، مجلس الثقافة العام سيرت، ليبيا،2006،

(5)- تودوروف:1939روسي الأصل لكنه مقيم في فرنسا ، أوضح معنى الثعرية، وحدد القو انين العامة

لو لوادة العمل الأدبي.

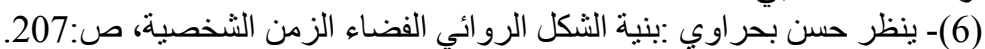

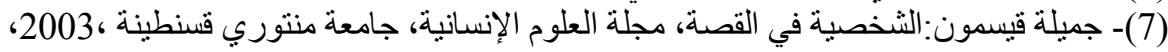

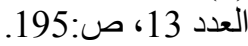

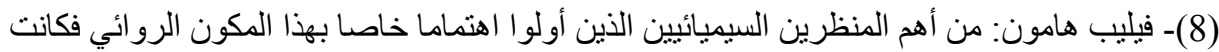

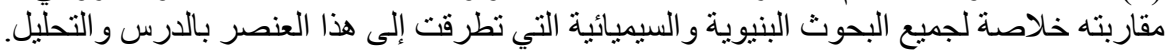

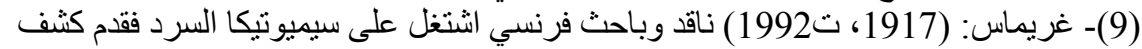

تخصص زمن القصة ومفهوم الروي.

* ألان روب غرييه: روائي وكاتب سيناريو ولائ ولد عام 1933 تلمبذ في المعهد الوطني الزراعي، مهندس زر اعي مكلف بمهة في المعهد الوطني للإحصاء (1945-1948)، ثماند في في معهد الإثمار و الحمضيات

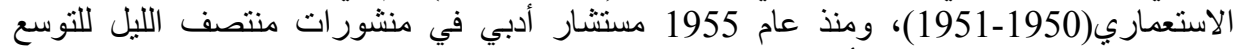

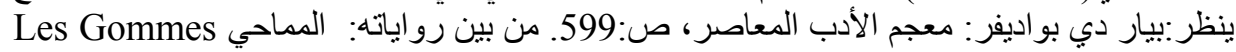

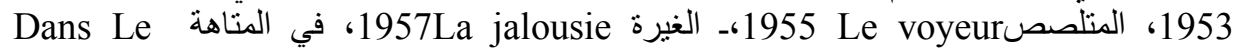
1961 L’ année Dernière à Marienbad وفينة 1959Labyrinthe

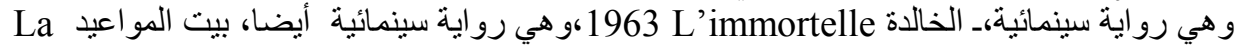

Projet Pour Une 1965،مشروع ثورة في نيويوركة Maison De Rendez Vous

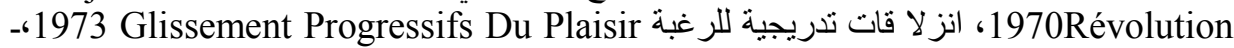

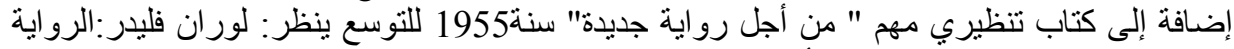

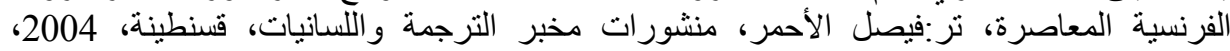
ص: ص:55. ** الشكلانية الروسية: هي حركة نقدية علمية نشطت بين سنتين(1915-1930) تشكلت من حلفتين:

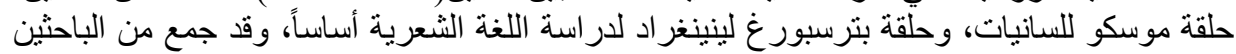

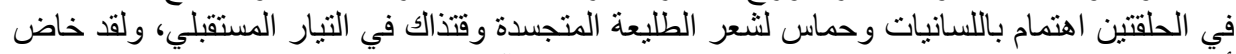

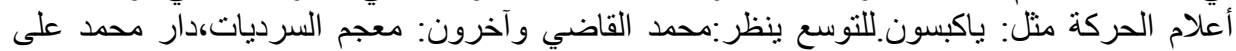

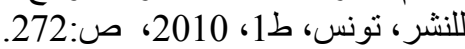

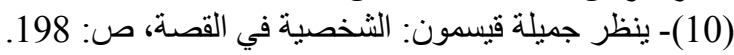

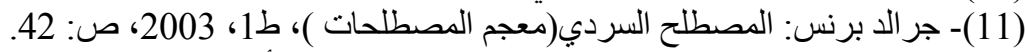

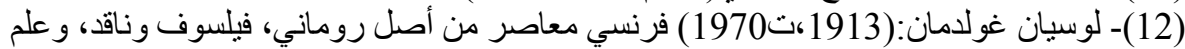

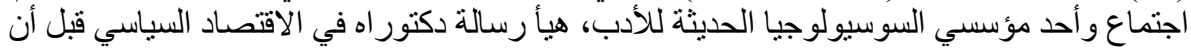

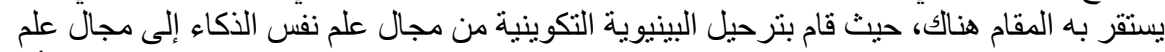

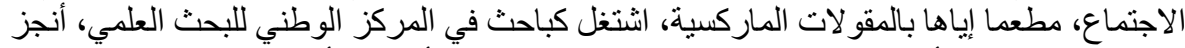
رسالة دكتور اه في الأدب بعنوان:(الإله المختفي:در اسة لرؤية المباريا المأساوية لأفكار باسكال ومسرح 
راسين)1956، نشر عدة كتب منها: (العلوم الإنسانية و الفلسفية) 1952 ثم وضع كتاب (أبحاث جلية)

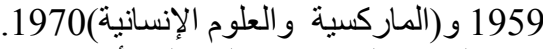

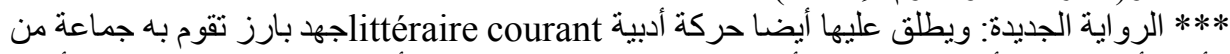

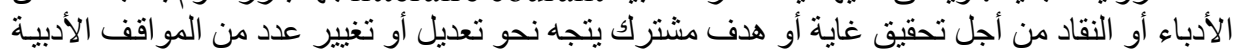

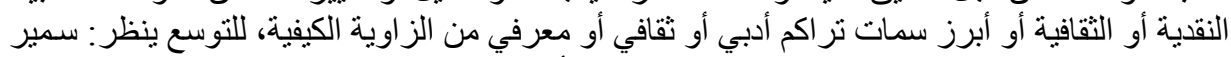

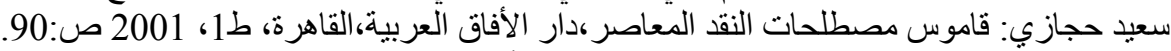
(13)- سمير سعيد حجازي: قاموس مصطلحات النقد الأدبي المعاصر ، دارية الآفاق العربية القاهرة، ط1،

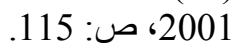

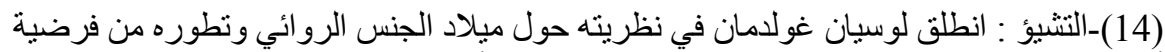

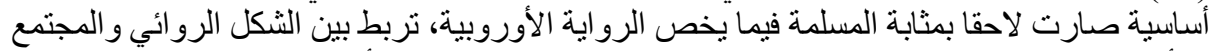

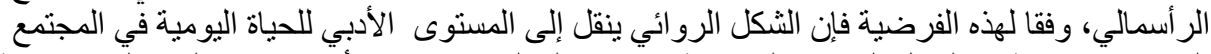

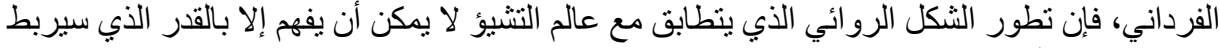

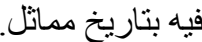

(15)- أمينة رشيد: قصة الأدب الفرنسي، دار شرقيات للنشر و التوزيع، القاهرة، مصر، ط1، 1996،

ص ص: 224 -225. 22 (15)

(16)- حسن بحر اوي: بنية الثكل الروائي، الفضاء الزمن، الثخصية، بيروت، الدار البيضـاء، ط1،

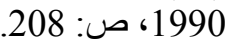

(17)- حسن بحر اوي: بنية الثكل الروائي، ط2، 2009، 2009، ص:208.

(18)- نعيم عطية: مأ الجديد في الرواية الجديدة، مجلة الفيصل الزئل الثقافية، الرياض، العدد الساد، السنة

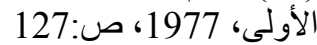

(19)- جـان ريكاردو: قضـايا الروايـة الحديثة، تر :صياح الجهيم، منشـورات وزارة الثقافة و الإرشـاد (القومي، دمشق، (1977)

(20)- فتحي العشري: لقاء مع ناتالي ساروت، مجلة الفيصل، دار الفيصل للثقافة، الرياض ، السعودية،

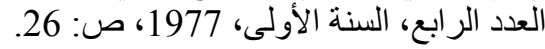

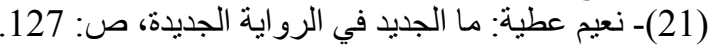

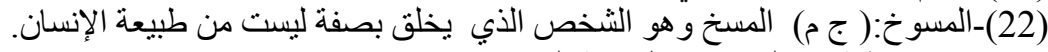

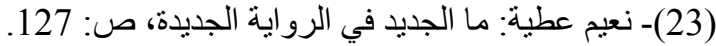

(24)- آلان روب غرييه : نحو رو اية جديدة ، تر :مصطفى إبر اهيم مصطفى، تقديم لويس عوض، دار

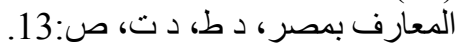

(25)- Jean Ricardou : le nouveau roman éditions seuil, paris, p p : 170-171.

(26)- محمد الباردي: الرواية العربية والحداثية، الرواية العراية العربية والحداثة، دار الحوار للنشر و التوزيع

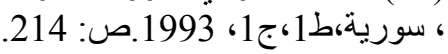

(27)- المرجع نفساه، صن صن: 218 218 219.

(28)- محمود قاسم: موسو عة أدباء نهاية القرن العشرين، الدار المصرية، اللبنانية، القاهرة مصر، ط1،

2000، ص: 195 (29) محرد

(29)- ر م ألبريس: تاريخ الرواية الحديثة، تر:جورج سـالم، منثور ات عويدات، بيروت،باريس،ط2،

1982. ص: 198

(31)- ينظر المرجع نفسه ، ص ص:470. :446-447.

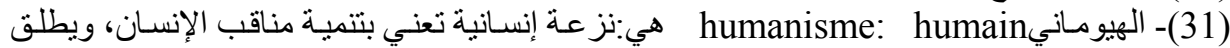

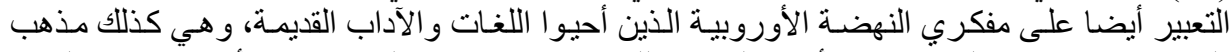

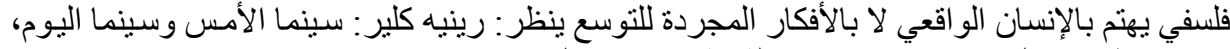

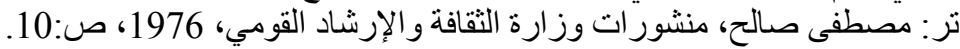




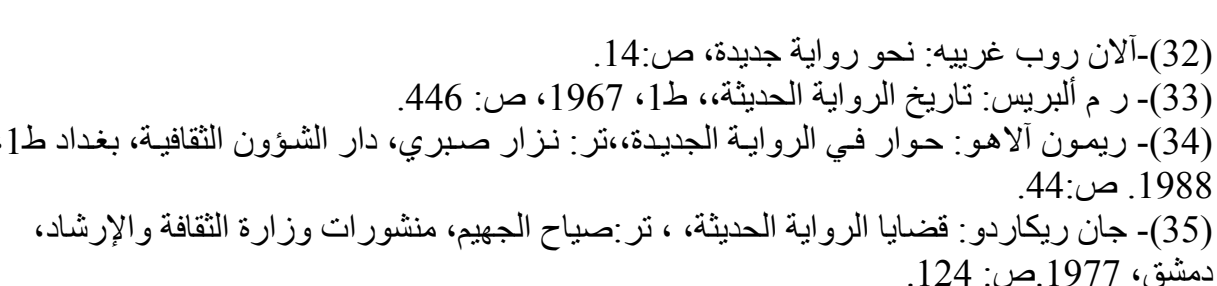

(36)- Alain Robbe Grillet : l'année dérnier à marienbad, Les édition de minuit, 1961.P : 13 .

(37)- Ibid. p:25.

(38)- رولان بارث: هسهة اللغة، تر : منذر عياثـي، مركز الإنماء الحضري، حلب، سوريا، ط1،

(39)- Alain Robbe Grillet : l'année dernière à marienbad, $\mathrm{p}: 28$.

(40) - ibid. p:29.

(41)-ibid. même page.

(42)-Alain Robbe Grillet : La Jalousie, les édition de minuit,1957.P : 08.

(43)- السعيد بوطاجين: الاشتغال العاملي در اسة سيميائية غدا يوم جديد لابن هدوقة عينة، منشورات الاختلاف، ط1، 2000، ص ص صل : 87-86.

(44)-Alain Robbe Grillet : La Jalousie, p :15.

(45)- Ibid. P : 21.

(46)-Alain Robbe Grillet : l'année dernier à marienbad, P : 29.

(47)-Alain Robbe Grillet : la jalousie, P : 23.

(48)-Ibid. P :23.

(49) -Alain Robbe Grillet : l'année dernier à marienbad, P : 45.

(50)- Ibid. Même Page.

(51)-Alain Robbe Grillet : l'année dernier à marienbad, P : 48.

(53)- Alain Robbe Grillet : la jalousie, P : .21

(54)- الكنين (La Quinine ) :و هي حبوب مهدأة كانت تستعمل من طرف مرضى الحمى أو لدفع ألام

(55)-Ibid. Même Page.

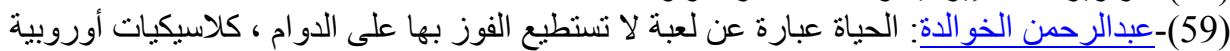

2017/03/13 201tps://filmmagazine.wordpress.com/, 